\title{
A description of mercury in fishes from the Madeira River Basin, Amazon, Brazil
}

Wanderley Rodrigues BASTOS ${ }^{1}$, Mauro de Freitas REBELO², Márlon de Freitas FONSECA³, Ronaldo de ALMEIDA ${ }^{4}$, Olaf MALM ${ }^{5}$

\section{ABSTRACT}

Over the last 20 years several projects carried on the Madeira River basin in the Amazon produced a great amount data on total $\mathrm{Hg}$ concentration in different fish species. In this paper we discuss temporal trends in $\mathrm{Hg}$ contamination and its relation to body weight in some of those fishes, showing that even within similar groups, such as carnivorous and non-migratory fish, the interspecies variability in $\mathrm{Hg}$ accumulation is considerable.

KEYWORDS: Fish, mercury, Biomagnification, Madeira River, Amazon.

\section{Um estudo descritivo do mercúrio em peixes da bacia do Rio Madeira, Amazônia, Brasil.}

\section{RESUMO}

Vários estudos têm sido desenvolvidos nos últimos 20 anos na bacia do Rio Madeira (Amazônia) com o objetivo de diagnosticar a presença de mercúrio em peixes e compreender o ciclo deste elemento no meio ambiente tropical. Neste artigo são discutidas tendências temporais na concentração de $\mathrm{Hg}$ e sua relação com a massa corporal de algumas espécies de peixes com diferentes hábitos alimentares, coletadas no Rio Madeira e no reservatório da hidroelétrica de Samuel, no Rio Jamari, Estado de Rondônia. Foi avaliada uma amostragem de peixes de 14 anos (1987 - 2000) com 86 espécies e um total de 1100 espécimes.

PaLAVRAS-CHAVE: Peixe, Mercúrio, biomagnificação, Rio Madeira, Amazônia.

1 Professor Adjunto, Universidade Federal de Rondônia, Laboratório de Biogeoquímica Ambiental Wolfgang C. Pfeiffer. Rodovia BR-346 km 9,5 Sentido Acre, Porto Velho, Rondônia. CEP: 78913-280. e-mail: bastoswr@unir.br

2 Professor Adjunto, Universidade Federal do Rio de Janeiro, Laboratório de Radioisótopos EPF do Instituto de Biofísica CCF. Av. Carlos Chagas Filho, 373 Bloco G, CCS, Cidade Universitária, Ilha Fundão, Rio de Janeiro, RJ. CEP: 21941-902. e-mail: mrebelo@biof.ufrj.br

${ }^{3}$ Universidade Federal do Rio de Janeiro, Laboratório de Radioisótopos EPF do Instituto de Biofísica CCF. Av. Carlos Chagas Filho, 373 Bloco G, CCS, Cidade Universitária, Illha Fundão, Rio de Janeiro, RJ. CEP: 21941-902. email: marlon@biof.ufrj.br

${ }_{4}^{4}$ Universidade Federal de Rondônia. Laboratório de Biogeoquímica Ambiental Wolfgang C. Pfeiffer. Rodovia BR-346 Km 9,5 Sentido Acre, Porto Velho, Rondônia. CEP: 78913-280email: ronaldoalmeida@unir.br

5 Professor Titular, Laboratório de Radioisótopos EPF. Diretor do Instituto de Biofísica CCF da Universidade Federal do Rio de Janeiro. Av. Carlos Chagas Filho, 373 Bloco G, CCS, Cidade Universitária, Ilha Fundão, Rio de Janeiro, RJ. CEP: 21941-902. e-mail: olaf@biof.ufrj.br 


\section{INTRODUCTION}

It has been estimated that between 2000 to 3000 tons of Hg's have been released in the middle of the Amazon environment and nowadays small gold extraction activities using $\mathrm{Hg}$ can still be found (Malm, 1998; Lacerda \& Salomons, 1998; Lacerda, 2003). About $60 \%$ of this mercury is believed to be were lost to the atmosphere and $40 \%$ went directly to the watercourses (Pfeiffer \& Lacerda, 1988). Although gold mining in the Brazilian portion of the Madeira River basin has decreased significantly from 1995 onwards to about 0.3 to 0.5 t.yr $^{-1}$ nowadays, the activities continued and even increased in the Bolivian side of the basin, and the $\mathrm{Hg}$ released there eventually drains into the Madeira River from its major Bolivian tributaries (Maurice-Bourgoin et al., 2000). It is also suggested that burning and deforestation would allow long term atmospheric mercury deposited on soils, to run-off into rivers, justifying the high $\mathrm{Hg}$ concentrations in areas without a gold mining history (Veiga et al., 1994; Lacerda, 1995; Malm, 1998). Studies performed in distant areas and without gold mining activities registrations in the high Negro River reveal elevated $\mathrm{Hg}$ concentrations, what it carries to consider its natural source (Fadini \& Jardim, 2001). Continually, deposited $\mathrm{Hg}$ in soils and sediments suffers continuous transformations and interactions with environmental compartments, which eventually transform and remobilize $\mathrm{Hg}$ to food chains, including the increase of its bioavailability through methylation (Malm et al., 1990; Roulet et al., 1998; Lacerda, 2003).

The aquatic biota plays an important role in the conservation of life and wealth in an ecological system acting in seed dispersion, nutrient enrichment of the aquatic system by the conversion of vegetable biomass in to animal tissues and excreta that acts as a natural fertilizer in lakes. The complex interaction of biologic factors (fish weight and diet) is species specific and is reflected in the variability of fish- $\mathrm{Hg}$ concentrations during high or low water habitats (Bastos et al, 2006).

Fish is one of the most important food resources of the Amazonian population, which has 30,000 fishermen and more than 70,000 directly related jobs. Little is known regarding $\mathrm{Hg}$ bioaccumulation as a function of hydrological cycles in the Amazonian ecosystem (Dorea \& Barbosa, 2007). Moreover, previous studies in the Amazon and other areas have determined that fish is the main route of mercury contamination to the population, especially villages along the river, where contaminated fish is the main protein source (Malm et al., 1995; Bastos et al, 2007). The tolerance limit recommended for consumption by the WHO is $0.50 \mathrm{mg} \cdot \mathrm{kg}^{-1}$ for carnivorous and $0.30 \mathrm{mg} \cdot \mathrm{kg}^{-1}$ for non-carnivorous fishes (IPCS, 1990). In Brazil, the Hg limits was set at $0.50 \mathrm{mg} \cdot \mathrm{kg}^{-1}$ for nor-carnivorous and $1.00 \mathrm{mg} \cdot \mathrm{kg}^{-1}$ for carnivorous fishes (MS, 1998).

Therefore, even with decreasing direct emissions, $\mathrm{Hg}$ contamination of soils, sediments and aquatic biological resources, fish in particular, is still an environmental concern to local and national environmental authorities.

\section{MATERIAL AND METHODS}

Our study concentrates on two main areas in the Rondônia and Amazonas states (Figure 1): The Madeira River and its main tributaries located downstream the Samuel's dam (the

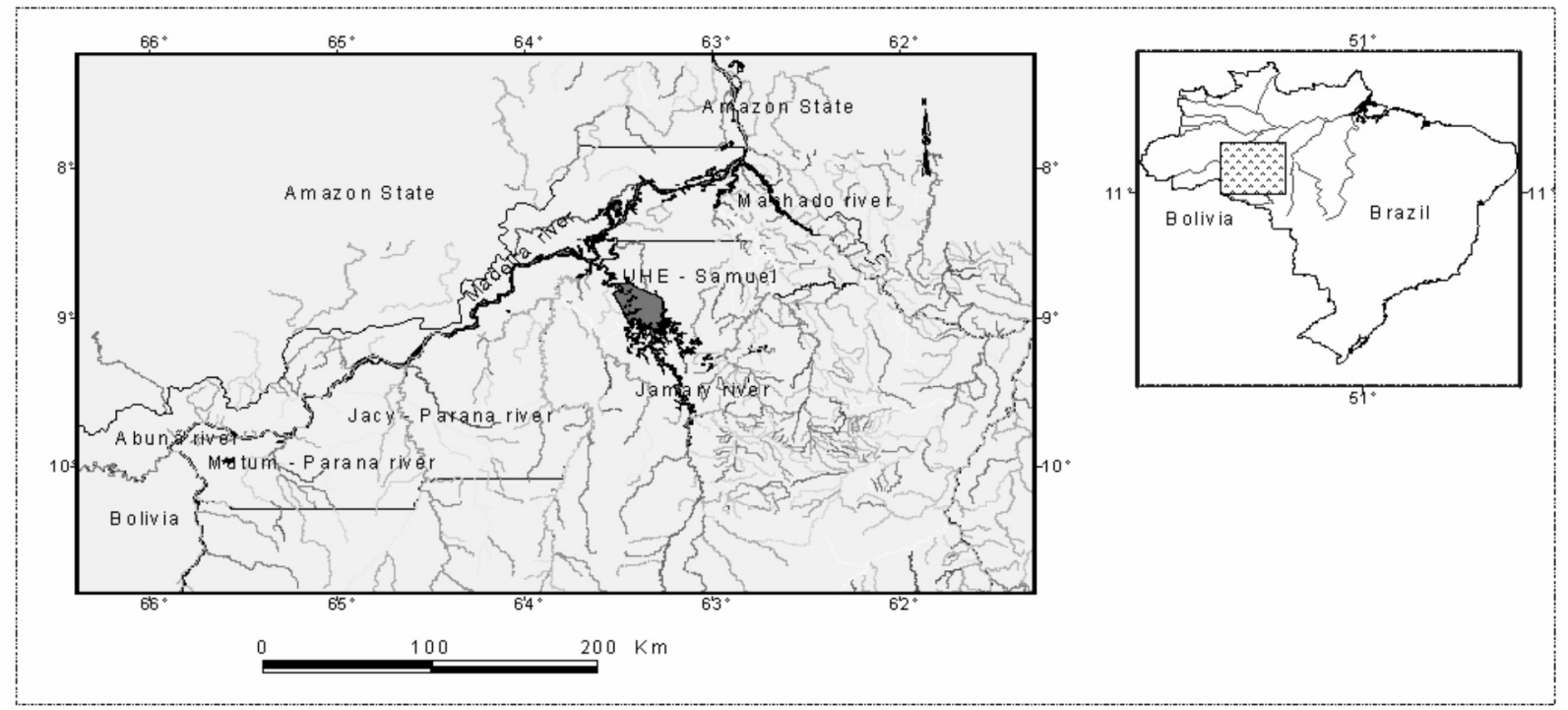

Figure 1 - Study area: The Madeira River basin in the Amazon forest, Brazil 
Jamari River), named here Madeira Complex; and the area upstream Samuel's dam concerning the Jamari River and the reservoir itself, named here Jamari River area.

Data presented here were collected in each area over the past 14 years by different groups, in several surveys carried out in both dry (May - October) and rainy seasons (December - March). All of the samples were transported in iceboxes to the Rondonia Federal University (UNIR) where they were catalogued and stored in freezers until analysis. Total mercury was extracted according to Bastos et al. (1998). Briefly, about $500 \mathrm{mg}$ of fish were digested in a microwave oven or a water bath (35 min) using $\mathrm{H}_{2} \mathrm{O}_{2}, \mathrm{H}_{2} \mathrm{SO}_{4}: \mathrm{HNO}_{3}(1: 1)$ and $\mathrm{KMnO}_{4}$ $5 \%$, with total $\mathrm{Hg}$ determinations by cold vapor atomic absorption spectrophotometer (CV-AAS, Flow Injection Mercury System-FIMS-400 Perkin-Elmer, Germany). All samples were done in triplicate and analyzed in parallel with internationally certified material (DORM-2, NRC-Canada) as well as standard samples (APPX-2958, APPX-2960 e AFPX5130) produced in our own laboratory.

\section{RESULTS AND DISCUSSION}

A total of 1,100 fishes from 86 species were collected and analyzed in the Madeira River basin between 1987 and 2000. The summarized data is presented in Table 1.

Table 1 - Mean, standard deviation, number of samples, maximum and minimum concentration $\left(\mathrm{mg}^{\left.-\mathrm{kg}^{-1}\right)}\right.$ of total mercury in Amazonian fishes, organized per species, common name (Santos et al., 1984) and preferential feeding habit. Bold fishes exhibit mean values above the threshold limit of 0.50mg. $\mathrm{kg}^{-1}$ (WHO, 1990).

\begin{tabular}{|c|c|c|c|c|c|}
\hline Common name & Scientific name & $\begin{array}{l}\text { Total Hg } \\
\left(\mathrm{mg} \mathrm{kg}^{-1}\right)\end{array}$ & $\mathbf{n}$ & $\operatorname{Max}$ & Min \\
\hline & PISCIVOROUS & & & & \\
\hline Peixe-Cachorro & $\begin{array}{l}\text { Acestrorhynchus } \\
\text { falcirostris }\end{array}$ & 1.292 & 02 & 1.682 & 0.903 \\
\hline Pirarucu & Arapaima gigas & 0.343 & 06 & 0.730 & 0.231 \\
\hline Peixe-Cachorro & $\begin{array}{l}\text { Hydrolycus } \\
\text { scomberoides }\end{array}$ & 0.722 & 31 & 2.473 & 0.230 \\
\hline Peixe-Cachorro & Hydrolycus sp. & 1.020 & 02 & 1.335 & 0.705 \\
\hline Apapá-amarelo & Pellona castealneana & 1.212 & 27 & 3.921 & 0.440 \\
\hline Apapá-branco & Pellona flavipinnis & 1.597 & 06 & 3.022 & 0.993 \\
\hline Apapá & Pellona sp. & 1.308 & 02 & 1.807 & 0.810 \\
\hline Pescada & $\begin{array}{l}\text { Plagioscion } \\
\text { squamosissimus }\end{array}$ & 0.449 & 41 & 1.100 & 0.002 \\
\hline \multirow[t]{2}{*}{ Peixe-Cachorro } & Rhaphiodon vulpinus & 0.939 & 26 & 2.506 & 0.405 \\
\hline & CARNIVOROUS & & & & \\
\hline Mandubé & Ageneiosus brevifilis & 0.851 & 13 & 1.390 & 0.250 \\
\hline Bicuda & $\begin{array}{l}\text { Boulengerella } \\
\text { ocellata }\end{array}$ & 1.019 & 07 & 2.129 & 0.303 \\
\hline $\begin{array}{l}\text { Piraíba or } \\
\text { Filhote }\end{array}$ & $\begin{array}{l}\text { Brachyplatistoma } \\
\text { filamentosum }\end{array}$ & 1.359 & 18 & 4.753 & 0.490 \\
\hline
\end{tabular}

\begin{tabular}{|c|c|c|c|c|c|}
\hline Common name & Scientific name & $\begin{array}{l}\text { Total Hg } \\
\left(\mathrm{mg} \cdot \mathrm{kg}^{-1}\right)\end{array}$ & $\mathbf{n}$ & Max & Min \\
\hline Dourada & $\begin{array}{l}\text { Brachyplatistoma } \\
\text { flavicans }\end{array}$ & 0.907 & 19 & 3.166 & 0.142 \\
\hline Piramutaba & $\begin{array}{l}\text { Brachyplatistoma } \\
\text { vaillanti }\end{array}$ & 0.090 & 01 & - & - \\
\hline Tucunaré & Cichla monoculus & 0.524 & 13 & 1.098 & 0.330 \\
\hline Tucunaré & Cichla ocellaris & 0.428 & 96 & 1.316 & 0.012 \\
\hline Tucunaré-açú & Cichla sp. & 0.305 & 02 & 0.420 & 0.189 \\
\hline Tucunaré-paca & Cichla temensis & 0.419 & 04 & 0.532 & 0.266 \\
\hline Jacundá & Crenicichla reticulata & 0.406 & 07 & 0.556 & 0.241 \\
\hline $\begin{array}{l}\text { Liro or Braço- } \\
\text { de-moça }\end{array}$ & $\begin{array}{l}\text { Hemisorubim } \\
\text { platyrhynchos }\end{array}$ & 0.575 & 19 & 1.553 & 0.087 \\
\hline Traíra & Hoplias malabaricus & 0.432 & 55 & 1.188 & 0.033 \\
\hline Jaú & Paulicea Iukteni & 0.571 & 04 & 0.722 & 0.313 \\
\hline Pirarara & $\begin{array}{l}\text { Phractocephalus } \\
\text { hemioliopterus }\end{array}$ & 0.727 & 02 & 1.301 & 0.153 \\
\hline Barba-chata & $\begin{array}{l}\text { Pinirampus } \\
\text { pirinampu }\end{array}$ & 1.232 & 24 & 2.214 & 0.049 \\
\hline $\begin{array}{l}\text { Coroatá or } \\
\text { Pirá-tucandira }\end{array}$ & $\begin{array}{l}\text { Platynematichthys } \\
\text { notatus }\end{array}$ & 1.195 & 10 & 2.258 & 0.547 \\
\hline Peixe-agulha & $\begin{array}{l}\text { Potamorrhaphis } \\
\text { guianensis }\end{array}$ & 0.302 & 01 & - & - \\
\hline Arraia & Potamotrygon sp. & 0.090 & 01 & - & - \\
\hline Surubim & $\begin{array}{l}\text { Pseudoplatystoma } \\
\text { fasciatum }\end{array}$ & 0.660 & 38 & 1.561 & 0.080 \\
\hline Pintado & $\begin{array}{l}\text { Pseudoplatystoma } \\
\text { sp. }\end{array}$ & 0.969 & 26 & 2.890 & 0.046 \\
\hline Piranha-caju & Pygocentrus nattereri & 0.510 & 25 & 1.184 & 0.036 \\
\hline Piranha & $\begin{array}{l}\text { Serrasalmus. } \\
\text { eigenmanni }\end{array}$ & 1.697 & 01 & - & - \\
\hline Piranha-preta & $\begin{array}{l}\text { Serrasalmus } \\
\text { rhombeus }\end{array}$ & 0.781 & 146 & 2.168 & 0.186 \\
\hline Piranha-branca & $\begin{array}{l}\text { Serrasalmus } \\
\text { spilopleura }\end{array}$ & 0.294 & 09 & 0.811 & 0.030 \\
\hline \multirow[t]{2}{*}{ Peixe-lenha } & $\begin{array}{l}\text { Sorubimichthys } \\
\text { planiceps }\end{array}$ & 0.871 & 01 & - & - \\
\hline & DETRITIVOROUS & & & & \\
\hline Curimatã & Curimata knerii & 0.378 & 01 & - & - \\
\hline Acari-bodó & Lipossarcus pardalis & 0.016 & 05 & 0.020 & 0.006 \\
\hline Branquinha & Potamorhina latior & 0.114 & 28 & 0.280 & 0.049 \\
\hline Curimbá & Prochilodus cf. beni & 0.088 & 05 & 0.123 & 0.059 \\
\hline Curimbá & Prochilodus nigicaus & 0.342 & 01 & - & - \\
\hline Curimatã & $\begin{array}{l}\text { Prochilodus } \\
\text { theraponura }\end{array}$ & 0.021 & 03 & 0.046 & 0.006 \\
\hline Acari-bodó & $\begin{array}{l}\text { Pterygoplichthys } \\
\text { gibbiceps }\end{array}$ & 0.464 & 04 & 0.644 & 0.111 \\
\hline \multirow[t]{2}{*}{ Acari-bodó } & Pterygoplichthys sp. & 0.041 & 01 & - & - \\
\hline & HERBIVOROUS & & & & \\
\hline Piau & Laemolyta varia & 0.151 & 16 & 0.412 & 0.035 \\
\hline Pacu & Mylossoma duriventre & 0.024 & 03 & 0.031 & 0.015 \\
\hline Pacu & Mylossoma sp. & 0.053 & 40 & 0.440 & 0.001 \\
\hline $\begin{array}{l}\text { Piau-cabeça- } \\
\text { de-meia }\end{array}$ & Schizodon fasciatum & 0.123 & 14 & 0.295 & 0.021 \\
\hline $\begin{array}{l}\text { Piau-cabeça- } \\
\text { gorda }\end{array}$ & Schizodon sp. & 0.117 & 10 & 0.404 & 0.020 \\
\hline
\end{tabular}




\begin{tabular}{|c|c|c|c|c|c|}
\hline Common name & Scientific name & $\begin{array}{l}\text { Total Hg } \\
\left(\mathrm{mg} \cdot \mathrm{kg}^{-1}\right)\end{array}$ & $\mathbf{n}$ & Max & Min \\
\hline \multirow[t]{2}{*}{ Piau-botafogo } & Shizodon vittatum & 0.038 & 03 & 0.076 & 0.016 \\
\hline & MICROPHAGOUS & & & & \\
\hline Mapará & $\begin{array}{l}\text { Hypophthalmus } \\
\text { edentatus }\end{array}$ & 0.516 & 24 & 0.898 & 0.084 \\
\hline Cascudo & Plecostomus sp. & 0.050 & 06 & 0.122 & 0.025 \\
\hline Curimatã & Prochilodus sp. & 0.118 & 49 & 0.338 & 0.003 \\
\hline Cuiu-cuiu & Pseudodoras niger & 0.153 & 02 & 0.176 & 0.130 \\
\hline \multirow[t]{2}{*}{ Jatuarana } & $\begin{array}{l}\text { Brycon cf. } \\
\text { melanopterus }\end{array}$ & 0.054 & 18 & 0.123 & 0.032 \\
\hline & OMNIVOROUS & & & & \\
\hline Jatuarana & $\begin{array}{l}\text { Argonectes } \\
\text { scapularis }\end{array}$ & 0.603 & 01 & - & - \\
\hline Matrinxã & Brycon sp. & 0.098 & 15 & 0.250 & 0.050 \\
\hline Pintadinho & $\begin{array}{l}\text { Calophysus } \\
\text { macropterus }\end{array}$ & 1.381 & 11 & 2.249 & 0.718 \\
\hline Cará & Cichlasoma spectabile & 0.291 & 03 & 0.594 & 0.041 \\
\hline Pirapetinga & Colossoma bidens & 0.057 & 04 & 0.121 & 0.025 \\
\hline Pirapetinga & $\begin{array}{l}\text { Colossoma } \\
\text { brachypomus }\end{array}$ & 0.014 & 04 & 0.024 & 0.010 \\
\hline Tambaqui & $\begin{array}{l}\text { Colossoma } \\
\text { macropomum }\end{array}$ & 0.126 & 08 & 0.335 & 0.020 \\
\hline Acaratinga & Geophagus proximus & 0.105 & 01 & - & - \\
\hline Acará & Geophagus sp. & 0.179 & 20 & 0.648 & 0.028 \\
\hline $\begin{array}{l}\text { Aracu- } \\
\text { flamengo }\end{array}$ & Leporinus fasciatus & 0.229 & 07 & 0.439 & 0.051 \\
\hline $\begin{array}{l}\text { Aracu-cabeça- } \\
\text { gorda }\end{array}$ & Leporinus friderici & 0.334 & 10 & 2.040 & 0.020 \\
\hline Aracu & Leporinus sp. & 0.100 & 01 & - & - \\
\hline Bacu & Lithodoras dorsalis & 0.013 & 01 & - & - \\
\hline Aruanã & $\begin{array}{l}\text { Osteoglossum } \\
\text { bicirrhosum }\end{array}$ & 0.294 & 10 & 1.162 & 0.026 \\
\hline Cascudinho & Pareiorhapis duseni & 0.034 & 08 & 0.055 & 0.010 \\
\hline Mandi & Pimelodus sp. & 0.263 & 17 & 0.561 & 0.082 \\
\hline Rhamdia & Rhamdia sp. & 0.061 & 01 & - & - \\
\hline Jaraqui & $\begin{array}{l}\text { Semaprochilodus } \\
\text { theraponera }\end{array}$ & 0.202 & 27 & 0.419 & 0.105 \\
\hline Piranha-branca & Serrasalmus sp. & 0.537 & 37 & 1.725 & 0.138 \\
\hline Sardinha & Triportheus elongatus & 0.189 & 17 & 0.583 & 0.017 \\
\hline
\end{tabular}

* Species above the WHO threshold marked in bold.

Fishes were grouped according to preferential feeding habits. Carnivorous fish were the best represented class with 34 species, from which 16 (8 commercially important) present a mean total $\mathrm{Hg}$ value above the WHO threshold $\left(0.50 \mathrm{mg} \cdot \mathrm{kg}^{-1}\right)$. The 9 exclusively piscivorous species, despite low commercial interest, were all above the WHO threshold, showing the importance of the mercury biomagnification. Also among omnivorous fishes (20 species) exhibited 4 species above of the WHO threshold (0.30 $\mathrm{mg}^{\mathrm{kg}}{ }^{-1}$ ), but except for jatuarana the other species don't have commercial importance. No herbivorous fish (6 spp.) has exhibited concentrations above the threshold value. In the 8 detritivorous species just 3 overcame the WHO threshold $\left(0.30 \mathrm{mg}^{-\mathrm{kg}^{-1}}\right)$.
The carnivorous Serrasalmus rhombeus $(\mathrm{n}=146)$, Hoplias malabaricus $(\mathrm{n}=55)$, Cichla ocellaris $(\mathrm{n}=96)$, Plagioscion squamosissimus $(\mathrm{n}=41)$; the detritivorous Prochilodus sp. $(\mathrm{n}=49)$ and the herbivorous Mylossoma sp. $(\mathrm{n}=40)$ were selected as the most frequent species in this 14 year survey to observe high mercury tendencies.

We have analyzed the correlation of total $\mathrm{Hg}$ concentration over the sampled years for these 6 species and the scatter plot with $\mathbf{r}$ values are presented in figure 2. Only Plagioscion squamosissimus and Hoplias gr. malabaricus have exhibited significant correlations $(\mathrm{p}<0.05)$ suggesting a decreasing tendency in the Madeira Complex. P. squamosissimus is an estuarine fish which might have a strong migratory behavior making it difficult to explain the observed decreasing pattern. C. ocellaris, which is a sedentary specie, has exhibited no pattern at all. H. malabaricus, which lives in ponds and still waters, has exhibited a decreasing pattern in spite of a high variation in total $\mathrm{Hg}$ concentration observed, for example, in 1996 when sampling was more abundant.

Seasonal variation was tested for each of these 6 selected species during the years of 1996 and 1997 when samples were more abundant and equally distributed all year long. The end of the dry and rainy season periods was characterized from August to October and February to April, respectively, according to the water level of the Madeira River exhibited in Figure 3. Once no significant differences ( $U$ test) were observed, both seasons were grouped for the further analysis. We also tested the difference in total $\mathrm{Hg}$ concentration for each of these species in the Madeira Complex and the Jamari River and this time C. ocellaris exhibited significant higher $(\mathrm{U}$ test; $\mathrm{p}<0.05)$ concentrations in the Madeira Complex while for $S$. rhombeus concentrations in Jamari River were significantly higher.

No significant correlation between length or weight and total $\mathrm{Hg}$ was found for any species in the Madeira Complex. According to Roulet \& Maury-Brachet (2001), it is rare to observe significant correlations in Amazonian fishes. In the Jamari River $H$. malabaricus and S. rhombeus exhibit a significant positive linear correlation. C. ocellaris exhibited no significant correlation even for the Jamari River area, where most fishes were sampled at the Samuel's reservoir, what could be important for sedentary specie like this. But it is also worth noting that we used much broader weight criteria than those authors.

We have also found no significant correlation for Mylossoma sp. or a significant negative linear relation for Prochilodus sp. in the Jamari River, which could be explained by a change in preferential feeding habits experienced from juvenile to adult age, a characteristic of these species. Scatter plots are presented in figure 4 . 

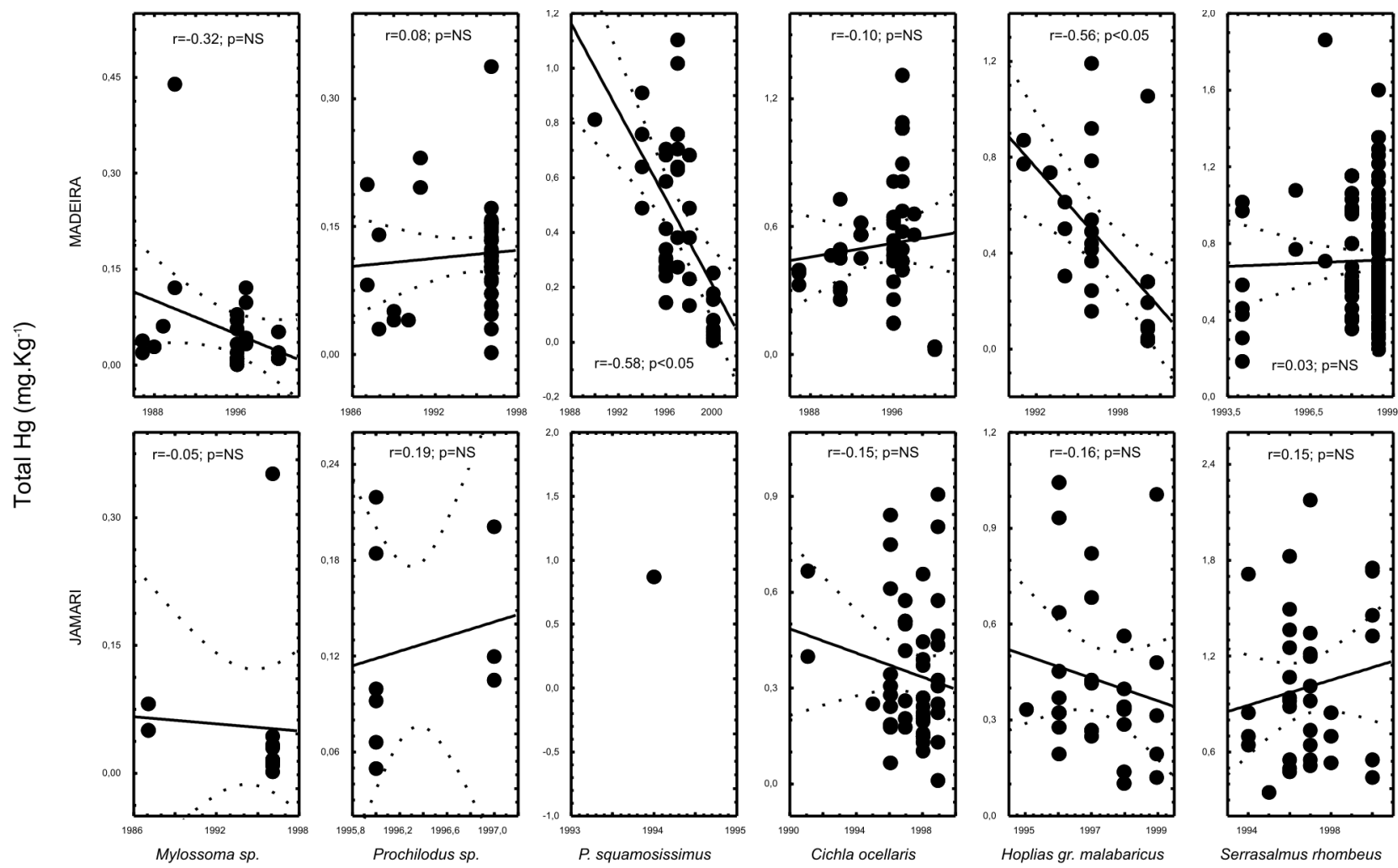

Figure 2 - Scatter plots of total $\mathrm{Hg}$ x year in the Jamari River and Madeira Complex. Correlation coefficients are presented in the graphics. Dashed lines are the confidence intervals.

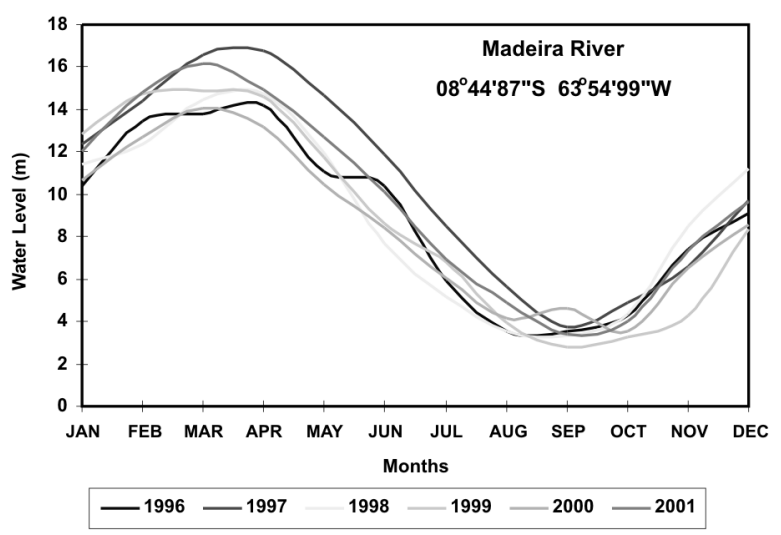

Figure 3 - Water average level in the Madeira River during the years of 1996 at 2001 characterizing the final of the dry and rainy seasons.

\section{CONCLUSIONS}

Sampling at a very complex environment like the Amazon for long periods is extremely difficult and expensive. Analyzing data from sporadic surveys over 14 years allows a more descriptive than quantitative assessment of the affect of mercury in fish. Little conclusions can be drawn from such heterogeneous data when parameters controlling mercury availability is so variable between inter and intra-species. It is possible that the choice of fewer species in a stratified sampling from now on would allow a more regular survey and thus, a more regular design of a long-term pattern of accumulation. This huge amount of data will be useful for further modeling approaches for better understanding the trends in Amazonian fishes. 

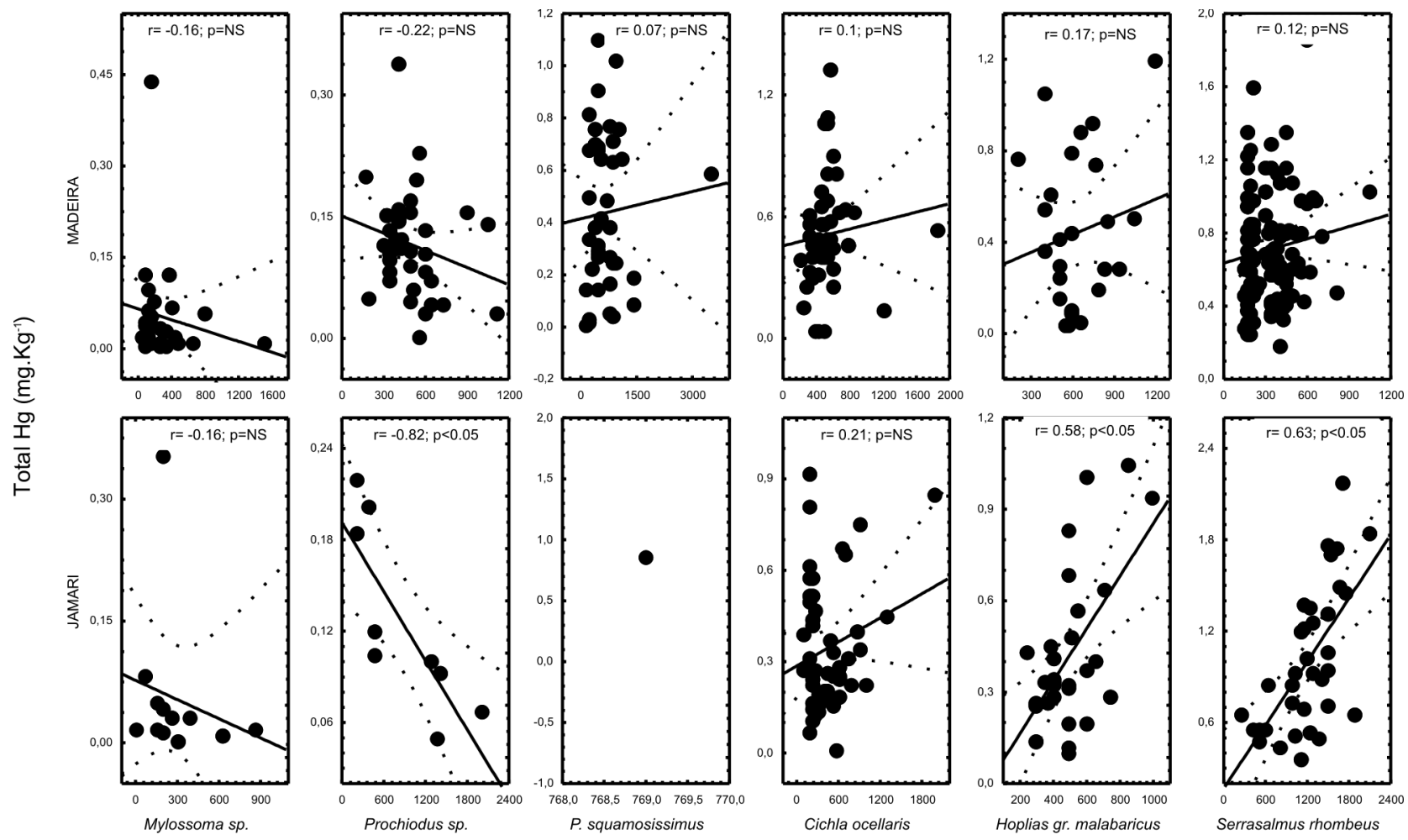

Weight (g)

Figure 4 - Scatter plots of total $\mathrm{Hg}$ x weight of some fish species in the Jamari River and Madeira Complex. Correlation coefficients are presented in the graphics. Dashed lines are the confidence intervals.

\section{ACKNOWLEDGEMENTS}

This work was supported by the CNPq (Conselho Nacional de Desenvolvimento Científico e Tecnológico) through CNPq/CT-Amazônia (Proc. N o.553269/2005-4 and CNPq/PPG-7 (Proc. №.556934/2005-9) projects. A special gratefulness to IBAMA (Instituto Brasileiro do Meio Ambiente e dos Recursos Naturais Renováveis) by the fishes species collection license (DIFAP/IBAMA No.091).

\section{LITERATURE CITED}

Bastos, W.R.; Malm, O.; Pfeiffer, W.C.; Cleary, D. 1998. Establishment and analytical quality control of laboratories for $\mathrm{Hg}$ determination in biological and geological samples in the Amazon, Brazil. Technical Review. Ciênc Cult. 50, 255-260.

Bastos, W.R.; Gomes, J.P.; Oliveira, R.C.; Almeida, R.; Nascimento, E.L.; Bernardi, J.V.E.; Lacerda, L.D.; Silveira, E.G.; Pfeiffer, W.C. 2006. Mercury in the environment and Riverside population in the Rio Madeira Basin, Amazon, Brazil. Sci Total Environ., 368: $344-351$.

Bastos, W.R.; Almeida, R.; Dórea, J.G.; Barbosa, A.C. 2007. Annual flooding and fish-mercury bioaccumulation in the environmentally impacted Rio Madeira (Amazon). Ecotoxicolog, 16(03): $341-346$
Dórea, J. G.; Barbosa, A C. 2007. Anthropogenic impact of mercury accumulation in fish from the Rio Madeira and Rio Negro rivers (Amazônia). Biological Trace Element Research, 115: 243-254.

Fadini, P.S.; Jardim, W.F. 2001. Is the Negro River Basin (Amazon) impacted by naturally occurring mercury? Sci Tot Environ, 275: 71-82.

IPCS. 1990. Environmental Health Criteria 101: Methyl-mercury. World Health Organization. Geneva. 141pp.

Lacerda, L.D. 1995. Amazon mercury emissions. Nature, 374: 20-21.

Lacerda, L.D.; Salomons, W. 1998. Mercury from Gold and Silver Mining: A Chemical Time Bomb. Springer Verlag, Berlin. 146pp.

Lacerda, L.D. 2003. Updating global mercury emissions from small-scale gold mining and assessing its environmental impacts. Environ Geol., 43: 308 - 314.

Malm, O.; Pfeiffer, W.C.; Souza, C.M.M.; Reuther, R. 1990. Mercury pollution due to gold mining in the Madeira River basin, Brazil. Ambio, 19: 11-15.

Malm, O.; Castro, M.B.; Bastos, W.R.; Branches, F.J.P.; Guimarães, J.R.D.; Zuffo, C.E.; Pfeiffer, W.C. 1995. An assessment of Hg pollution in different goldminning areas, Amazon Brazil. Sci Total Environ., 175: 127-140. 
Malm, O. 1998. Gold mining as a source of mercury exposure in the Brazilian Amazon. Environ Res., 77: 73-78.

Maurice-Bourgoin. L.; Quiroga, I.; Chincheros, J.; Courau, P. 2000. Mercury distribution in waters and fishes of the upper Rio Madeira and mercury exposure in riparian Amazonian populations. Sci Total Environ, 260: 73-86.

MS - Ministério da Saúde. 1998. Princípios gerais para o estabelecimento de níveis máximos de tolerância para contaminantes inorgânicos: Limites máximos de tolerância para contaminantes inorgânicos. Secretaria de Vigilância Sanitária, Agência Nacional de Vigilância Sanitária. Portaria no. 685 de 27.08.98, DOU de 28.08.1998.

Pfeiffer, W.C.; Lacerda, L.D. 1988. Mercury inputs to the Amazon region, Brazil. Environ Technol Lett., 9: 325-350.

Roulet, M.; Lucotte, M.; Saint-Aubin, S.; Heault, I.; Farella, I.; Silva, E.J.; Dezencourt, J.; Souza Passos, C.J.; Soares, G.S.; Guimarães, J.R.; Mergler, D.; Amorim, M. 1998. The geochemistry of mercury in central Amazon soils developed on the Alter do Chão formation of the lower Tapajós River valley, Pará State, Brazil. Sci Total Environ, 223(1): 1-24.

Roulet, M.; Maury-Brachet, R. 2001. Le mercure dans les organisms aquatiques amazoniens. In: Carmouse, J.P., Lucotte, M., Boudou, A., (Eds). Le mercure en Amazonie. Rôle de L'homme et de L'environment, risques sanitaries. IRD editions. Paris. 494pp.

Santos, G.M.; Jegu, M.; Merona, B. 1984. Catálogo de peixes comerciais do baixo rio Tocantins. Projeto Tucuruí. Eletronorte/ CNPq/INPA. Manaus. 83pp.

Veiga, M.M.; Meech, J.A.; Onate, N. 1994. Mercury pollution from deforestation. Nature, 368: 816-817.

Recebido em 27/03/2006

Aceito em 10/06/2008 
